\title{
Host-Parasitic Relationships between Tetrastigma rafflesiae and Rafflesia azlanii and Rafflesia cantleyi in Belum-Temenggor Forest Complex, Perak, Malaysia
}

\author{
Syarifah Haniera Sheikh Kamal', Mohd Nazip Suratman ${ }^{1,2 *}$, Shamsul Khamis ${ }^{3}$, \\ Ahmad Najmi Nik Hassan ${ }^{4}$ and Mohd Syaiful Mohammad ${ }^{4}$ \\ ${ }^{1}$ Faculty of Applied Sciences, Universiti Teknologi MARA, 40450 Shah Alam, Selangor, Malaysia \\ ${ }^{2}$ Institute for Biodiversity and Sustainable Development, Universiti Teknologi MARA, 40450 Shah Alam, \\ Selangor, Malaysia \\ ${ }^{3}$ Faculty of Science and Technology, Universiti Kebangsaan Malaysia, 43600 Bangi, Selangor, Malaysia \\ ${ }^{4}$ Pulau Banding Foundation, Level 11, Tower 1, Mercu Mustapha Kamal, Jalan PJU 8/1, Damansara Perdana, \\ 47820 Petaling Jaya, Selangor, Malaysia
}

\begin{abstract}
Rafflesia is a holoparasitic plant that depends solely on its host for its nutrients, given that during the early stage of its life, this parasite lives inside the host vine. The lack of host specificity and preference information for Rafflesia can largely be attributed to the absence of a comprehensive taxonomic study in Tetrastigma. Without the host, the Rafflesia will not be able to survive. Therefore, this research was conducted to study the host-parasitic relationships between the two species using anatomical dissection and micrographic images using a light microscope (LM) and scanning electron microscope (SEM). The anatomical study consisted of three stages of Rafflesia buds; the emergence of cupule stage, cupulebract transition stage, and bract stage attached with the host. All samples underwent sliding techniques and were observed using LM and

ARTICLE INFO

Article history:

Received: 19 May 2021

Accepted: 24 August 2021

Published: 3 November 2021

DOI: https://doi.org/10.47836/pjtas.44.4.04

E-mail addresses:

syarifahhaniera@gmail.com (Syarifah Haniera Sheikh Kamal)

nazip@uitm.edu.my (Mohd Nazip Suratman)

shamsulk@ukm.edu.my (Shamsul Khamis)

nunjimmimya@gmail.com (Ahmad Najmi Nik Hassan)

sifu_nyetok@yahoo.com (Mohd Syaiful Mohammad)

*Corresponding author

SEM. Based on the results, the anatomical characteristics of the host-parasite for the cupule stage evidenced penetration of the parasite-affected tissues inside the vascular bundles with the visibility of the flower bud. However, during other stages, the penetration of parasite-affected tissues to the vascular bundles was disrupted and cannot be seen using this sliding technique. The endoparasite of Rafflesia invades the
\end{abstract}


host only towards the phloem region in the early stage. In contrast, in late buds for both species, the Rafflesia tissue invaded both the host xylem (proximal region) and phloem. The parasite intrusion movement for both Rafflesia species showed a pointed tissue towards the host as this was believed to minimise the damage of the host plant. A new method using the paraffin wax technique might improve the sectioning and provide a more precise relationship dissection. The information from this study is expected to provide baseline information and an understanding of the host-parasitic relationship between the species. In addition, further anatomical studies with the different stages of buds will offer a better understanding of their relationship with the host.

Keywords: Holoparasite, host-parasite, Rafflesia azlanii, Rafflesia cantleyi, Tetrastigma rafflesiae

\section{INTRODUCTION}

Approximately 4,530 of the 369,000 flowering plant species (1.2\%) are parasitic and had evolved at least 12 times across the angiosperms (Bell et al., 2011; Těšitel, 2016; Twyford, 2018). Parasitic plants can be divided based on photosynthetically active hemiparasites, or holoparasitic due to a lack of photosynthetic activity. They rely entirely on a host for carbon, whether they are facultative or obligate parasites and whether they attach to the host's roots or stem (Twyford, 2018). Rafflesia is a holoparasitic plant with no chlorophyll and depends solely on its host for its water and nutrients (Wicaksono, 2015). Parasitic plants have long inspired interest from botanists, horticulturalists, and evolutionary biologists because they directly connect with a suitable host plant, allowing them to absorb nutrients and water from the host (Twyford, 2017). A modification of host metabolism and morphology was accomplished through specific parasites' structures called haustoria (Cocoletzi et al., 2016). Cameron et al. (2007) reported that the ability of haustorium to access the host's vascular tissue and withdraw resources is a crucial adaption that needs to be understood more. Twyford (2018) reported that holoparasites develop terminal haustoria at the meristematic tip of the primary root, then penetrate the host epidermis and cortex, and attach to the host vasculature followed by further plant growth, flowering, and senescence. Holoparasites are predominantly phloem feeders that typically retain a xylem connection and obtain all mineral nutrients, amino acids, soluble carbon, and water from the host. Hemiparasites are predominantly xylem feeders that obtain reduced carbon and nitrogen from the host. Hibberd and Jeschke (2001) reported that some 3,000 species of parasitic angiosperm among 17 families had been documented. Unfortunately, only a small number of these parasitic plants have been studied.

Mursidawati and Sunaryo (2012) studied the general observation of the Rafflesia patma Blume endophytes within its host plant. Their study observed three phases of $R$. patma growth: penetration, 
invasion, and establishment. The penetration phase occurred during the early germination stage. In this invasion phase, the flower bud starts to grow and affect the host tissue, the establishment phase where the flower establishes as a mature flower bud prior to anthesis. Later updated in Mursidawati and Irawati (2017), the fourth phase, named the conductive stage, involved flower establishment and saw nutrients were obtained from the host.

In another study, Nikolov et al. (2014a) conducted a study on Rafflesia cantleyi Solms-Laubach, Rafflesia tuan-mudae Becc., Rhizanthes lowii (Becc.) Harms and Sapria himalayana Griffith on the flower development and the endophytic movement within its host plant. The study revealed that the endophyte was probably developed directly from proembryo instead of an embryo proper and concluded that Rafflesiaceae produced modified vegetative bodies that differed from other holoparasitic angiosperms once grouped with Rafflesiaceae.

Mursidawati et al. (2019) studied patma and Tetrastigma rafflesiae (Miq.) Planch in which the former grew from a protocorm inside the cambium tissue of the latter. Rafflesia patma spread within $T$. rafflesiae vascular cambium tissue linearly, but not as a continuous strand. It was suspected that the parasitic endophyte spread inside the host vascular cambium and was pushed farther away from its origin point to another part of the host as the host vine cambium fusiform initial cells divided and enlarged over months. It resulted in the endophyte not forming a long continuous strand, analogous to a fungal mycorrhizal hyphal network, within its host plant, but instead forms small meristematic cell clusters that spread as the vascular cambium expands, allowing it to be squeezed out between initial fusiform cells and spread through the host body. A recent study on tissue differentiation of early and late bud flowers of $R$. patma was conducted by Mursidawati and Wicaksono (2020). They revealed the three types of flower tissues: proximal region and tissue with non-elongated cells in the middle and distal regions. There has been limited understanding of the host-parasite association and variation in collecting and attracting host solutes. More studies are needed especially related to the host-parasitic relationship, to compare the species and different stages of buds. This study aimed to gain a better understanding of the host-parasitic relationship between Rafflesia and Tetrastigma species. The study of host-parasitic relationships between Rafflesia and Tetrastigma may provide the opportunity to understand the pathways and cells involved in the solute transfer and the physiological impact of changes in the cell structure caused by the presence of the parasite itself.

\section{METHODS}

\section{Study Site and Field Data Collection}

This study was conducted in BelumTemenggor Forest Complex (BTFC) with the coordinate of $5^{\circ} 20^{\prime} 0^{\prime \prime}$ North, $101^{\circ} 22^{\prime}$ 0 " East. The area is the biggest continuous forest complex in Peninsular Malaysia 
in Perak (Razak et al., 2015). BelumTemenggor has a tropical climate with an annual rainfall reaching 3,000 $\mathrm{mm}$ per year with an average temperature throughout the year ranges from 24 to $29.9^{\circ} \mathrm{C}$ (Aiman Hanis et al., 2014). The humidity ranges from $70 \%$ to $98 \%$, with high rainfall in April and October and low rainfall in February and July (Aiman Hanis et al., 2014). BTFC consisted of Royal Belum State Park, Gerik Forest Reserve, Banding Forest Reserve, Amanjaya Forest Reserve, and Temenggor Forest Reserve (Malaysian Nature Society [MNS], 2013). This study consisted only of Gerik Forest Reserve and Banding Forest Reserve (Figure 1).

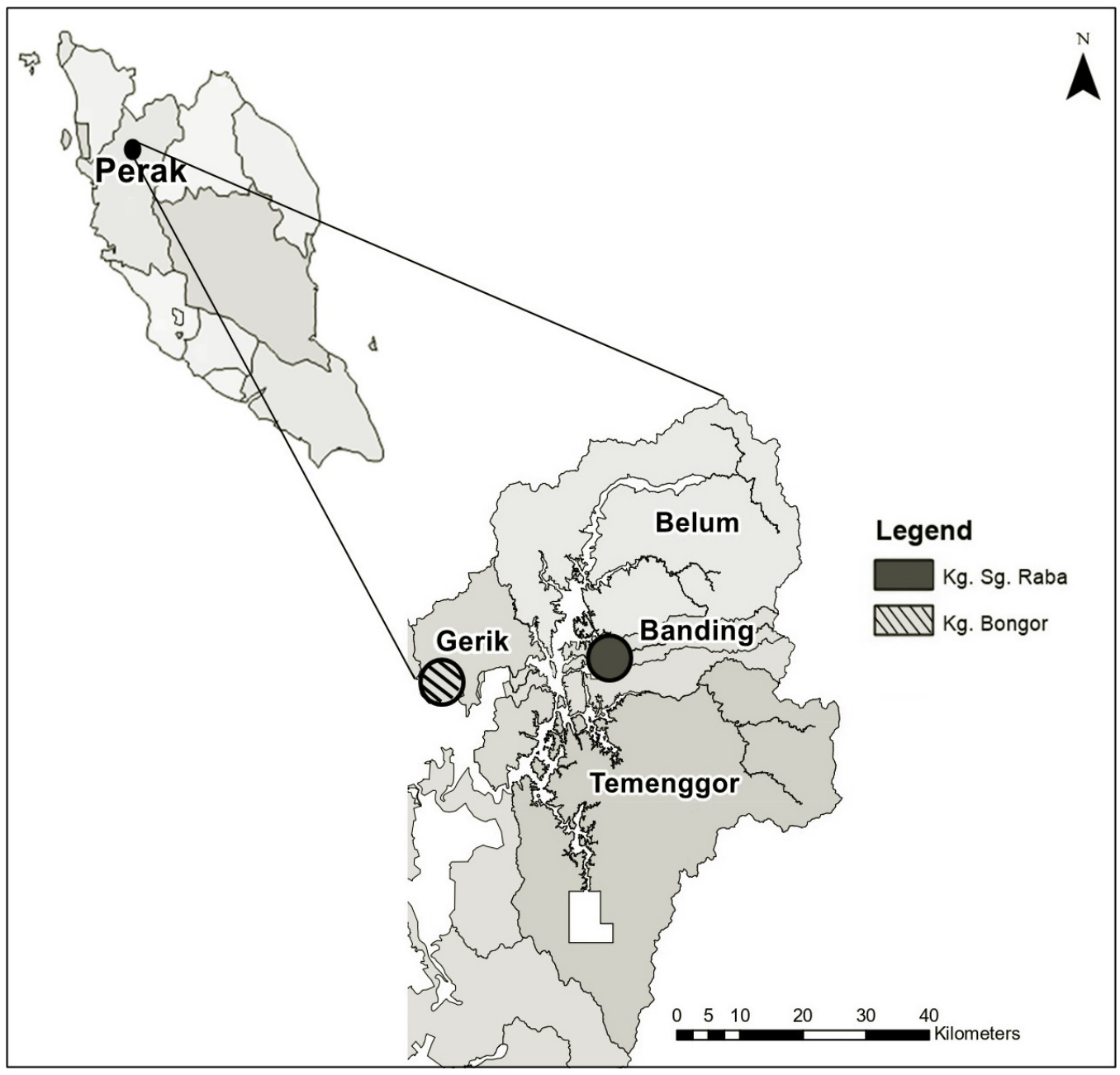

Figure 1. Location of study sites represented in circles 
The samples collected consisted of three stages of Rafflesia buds referred to by Susatya (2020) attached with the Tetrastigma vine (Figure 2). These are (1) cupule stage, where the emergence of cupule stage is marked as $\mathrm{cp}$ in the figure, (2) cupule-bract transition stage (CBT), where the bracts are present when the cupule parts (host tissue) are primarily seen and gradually replaced by bracts marked as 'br', (3) bract stage which referred as a visible bud that fully covered by bracts where the host tissues are no longer can be seen on top of the bud. From the field observation, the number of bud samples between the $R$. azlanii Latiff \& M. Wong and $R$. cantleyi species is not equal. For $R$. azlanii, only the cupule stage samples were collected and whereas for $R$. cantleyi, only the CBT stage and bract stage. In addition, Young $T$. rafflesiae stems and roots were collected to study the anatomical features of the host plant. One of the authors, a taxonomist from Universiti Kebangsaan Malaysia (UKM) involved in the identification process.

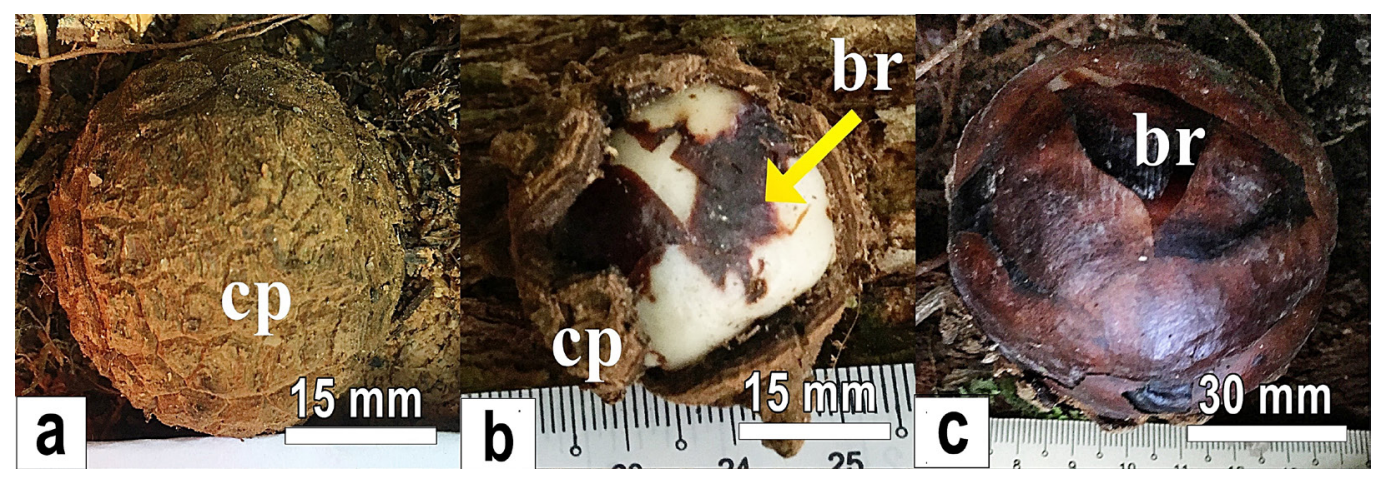

Figure 2. The bud development stage of Rafflesia: (a) cupule stage of Rafflesia azlanii, (b) cupule-bract transition stage of Rafflesia cantleyi, (c) bract stage of Rafflesia cantleyi

Note. $\mathrm{cp}=$ Cupule; br $=$ Bract

Samples obtained from the field underwent the process of fixation, which involved a preparation process in a bottle containing concentrated acetic acid (AA): $70 \%$ alcohol with a ratio of $1: 3$ with a minimum of 48 hours. Voucher specimens of slides (UKMB40462, UKMB40463, and UKMB40464) were deposited at the Herbarium Unit, UKM.

\section{Anatomical Method}

The collected samples (Figure 3) were preserved in the AA solution and transferred to $70 \%$ ethanol for the fixation process and long-term storage. Then, they were sectioned by freehand using a sliding microtome (Leica SM2000R, Leica Camera, Germany) at a thickness of 10-15 $\mu \mathrm{m}$. According to Tolivia and Tolivia (1987), the 
samples were then stained using a few drops of safranin, Alcian blue with distilled water, dehydrated with 50\%, 70\%, 95\%, and 100\% alcohol mounted using Eupharal on the slides. Anatomical features were observed and captured using a light microscope (Olympus VS120, Olympus Corporation, Germany) with an attached digital camera.

For the micrographology study using $\mathrm{SEM}$, the samples were cut into $1 \mathrm{~cm}^{2} \times 1$ $\mathrm{cm}^{2}$ and oven-dried for a week before the samples were completely dried up to the critical point. The specimens were placed in a drying device for 30 minutes and then affixed to the stab using a double face or colloidal silver cellophane sticker. The samples were routed to the top for scanning electron microscopy. The gold plating was conducted using a plating machine (Bal-Tec SCD 050, BalTec Corporation, USA). The observation process was conducted using the electron scanning microscope (Philips XL-30, Philips, the Netherlands) using a series of enlargements of $150 \times, 300 \times, 700 \times$, $1,000 \times, 5,000 \times$, to $10,000 \times$. From the slides, anatomical features were observed, and the features were described and characterised.

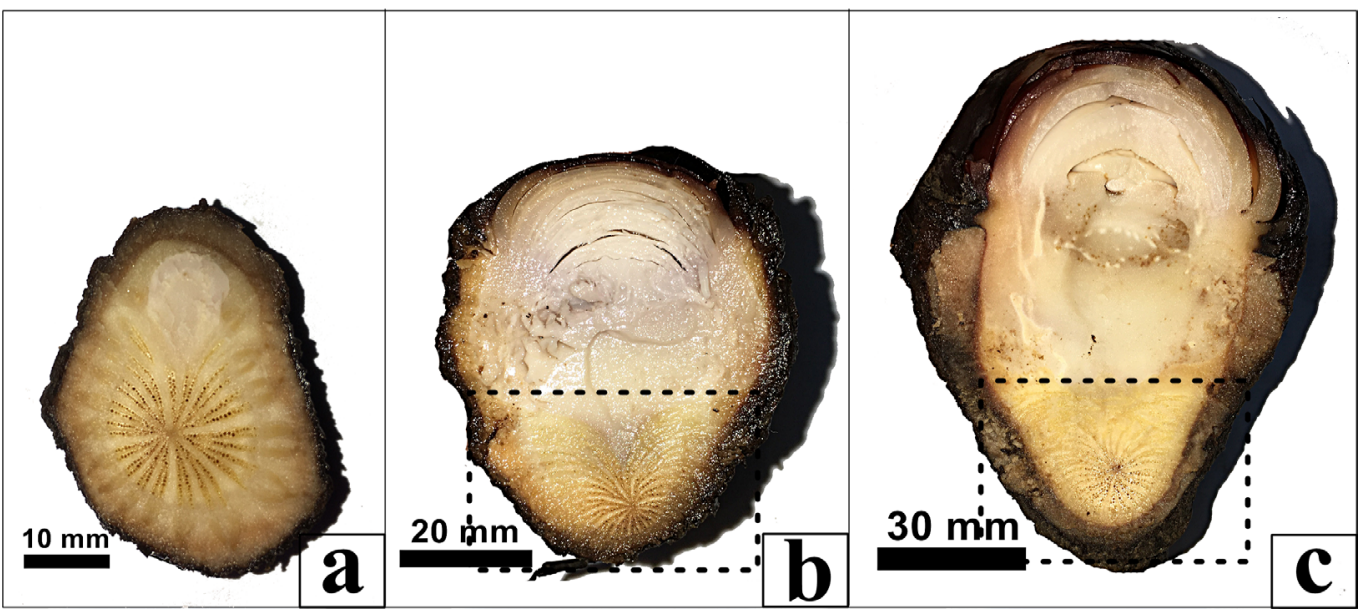

Figure 3. The transverse section of buds with the host: (a) cupule stage of Rafflesia azlanii, (b) cupule-bract transition stage of Rafflesia cantleyi, (c) bract stage of Rafflesia cantleyi. The dotted area referred to the anatomical part used in the study

Note $. \mathrm{cp}=$ Cupule; br $=$ Bract

\section{RESULTS AND DISCUSSION}

\section{Anatomy under Micrographology LM}

Non-parasite of Tetrastigma rafflesiae.

Figures 4(a) and 4(b) show T. rafflesiae root and stem images under the transverse section. Figure 4(a) is the root portion, and Figure 4(b) is the young stem of the host. Observation on the root image indicated a layer of periderm cell marked as 'PER' located at the root's outer surface, with a bit 
of pith located in the centre of the root stem near the vascular bundle. The small cortex (C) in Figure 4 can be seen between the periderm and vascular bundles, consisting of a few layers of parenchyma tissues. The vascular bundles are radially arranged alternately with eight branches of phloems $(\mathrm{PH})$ and xylems (XY) (Figure 4). The vascular cambium contains meristematic tissues that lie between the phloem and xylem tissues. For the young stem shown in Figure 4(b), there is also one layer of the epidermis but a large pith located near the vascular bundles in the centre of the root stem. A small cortex between the epidermis and vascular bundles consists of 12 to 15 layers of parenchyma cells and vascular bundles. They are enclosed with a single ring that contains 50 branches of phloems and xylems. The vascular bundles of non-parasitised hosts clearly show the presence of xylems and phloems without any disruption from the parasite tissues.
The primary phloems are associated with a sizeable pericyclic fibre strand (Pace et al., 2018) on its outermost part, as shown in Figure 4(a) and Figure 4(b). The descriptions of anatomical characteristics given below are based on the summary of specimens examined. Results from detailed measurements are presented in Table 1.

The early stages of wood lianas show a self-supporting phase. They are adapted to grow across gaps and reach host supports, whereby older stages can absorb and reduce potentially catastrophic mechanical stresses resulting from the movement of the host plant (Lopes et al., 2008). Therefore, there is a structural difference between young stem or old and root or stem part. The root of $T$. rafflesiae shows a thick layer of parenchyma under the periderm, while the young stem only has a single layer of parenchyma. This thick periderm was to allow the root to penetrate inside the ground easier. Syamsurina (2018) mentioned that

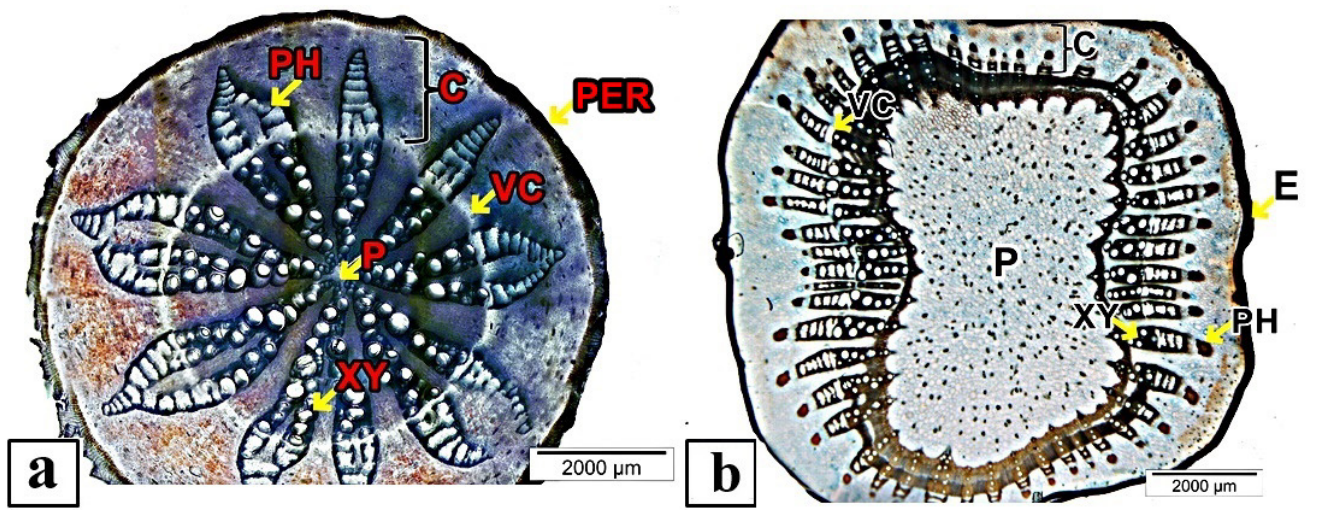

Figure 4. Transverse section of (a) Tetrastigma rafflesiae root, (b) young Tetrastigma rafflesiae stem (Scale: $\mathrm{a}, \mathrm{b}=2,000 \mu \mathrm{m})$

Note. $\mathrm{P}=$ Pith $; \mathrm{E}=$ Epidermis; $\mathrm{PER}=$ Periderm; $\mathrm{C}=\mathrm{Cortex} ; \mathrm{PH}=\mathrm{Phloem} ; \mathrm{VC}=$ Vascular cambium; $\mathrm{XY}=$ Xylem 
the T. rafflesiae root contains more layers of pith (Table 1). The vascular bundles of the the epidermis to protect the root as it will go stem have six times the branches compared deep inside the ground with compact soil. to the root. However, the length of vascular The difference between the roots and stems bundles in the root is three times longer than of the host is the pith structure of the stem in the stem.

and is 23 bigger in length size than the root

Table 1

Anatomical characteristics measurements (mean) of Rafflesia azlanii, Rafflesia cantleyi, and Tetrastigma rafflesiae

\begin{tabular}{|c|c|c|c|c|c|}
\hline \multirow[t]{2}{*}{ Characteristics } & \multicolumn{2}{|c|}{ Tetrastigma rafflesiae } & \multirow{2}{*}{$\begin{array}{c}\text { Tetrastigma } \\
\text { rafflesiae } \\
\text { with Rafflesia } \\
\text { azlanii } \\
\text { Cupule stage }\end{array}$} & \multicolumn{2}{|c|}{$\begin{array}{c}\text { Tetrastigma } \\
\text { rafflesiae } \\
\text { with } \\
\text { Rafflesia cantleyi }\end{array}$} \\
\hline & Root & Stem & & $\begin{array}{l}\text { CBT } \\
\text { stage }\end{array}$ & $\begin{array}{l}\text { Bract } \\
\text { stage }\end{array}$ \\
\hline $\begin{array}{l}\text { Thickness of epidermis/ } \\
\text { periderm }(\mu \mathrm{m})\end{array}$ & 252 & 201 & 442 & 430 & 357 \\
\hline Length of pith $(\mu \mathrm{m})$ & 224 & 5,318 & 191 & 486 & 662 \\
\hline $\begin{array}{l}\text { Distance from } \\
\text { epidermis/periderm to } \\
\text { pith }(\mu \mathrm{m})\end{array}$ & 6,503 & 2,490 & 6,536 & 10,752 & 15,885 \\
\hline Cortex length $(\mu \mathrm{m})$ & 1,657 & 1,570 & 1,836 & 2,611 & 5,408 \\
\hline Vascular bundle shape & Alternate & $\begin{array}{l}\text { Enclosed } \\
\text { with } \\
\text { single ring }\end{array}$ & Alternate & Alternate & Alternate \\
\hline $\begin{array}{l}\text { No. of vascular bundle } \\
\text { branch }\end{array}$ & 8 & 50 & 7 & $8-9$ & $12-14$ \\
\hline $\begin{array}{l}\text { Distance from vascular } \\
\text { cambium to epidermis/ } \\
\text { periderm }(\mu \mathrm{m})\end{array}$ & 1,770 & 1,140 & 2,604 & 2,786 & 9,434 \\
\hline $\begin{array}{l}\text { Length of vascular } \\
\text { bundle }(\mu \mathrm{m})\end{array}$ & 5,522 & 1,659 & 4,332 & 8,073 & Not clear \\
\hline $\begin{array}{l}\text { Length of parasite- } \\
\text { affected tissue (longest) } \\
(\mu \mathrm{m})\end{array}$ & $\begin{array}{c}\text { Not } \\
\text { applicable }\end{array}$ & $\begin{array}{c}\text { Not } \\
\text { applicable }\end{array}$ & 5,422 & Not clear & Not clear \\
\hline $\begin{array}{l}\text { Distance from parasite- } \\
\text { affected tissue to } \\
\text { epidermis }(\mu \mathrm{m})\end{array}$ & $\begin{array}{c}\text { Not } \\
\text { applicable }\end{array}$ & $\begin{array}{c}\text { Not } \\
\text { applicable }\end{array}$ & 6,366 & Not clear & Not clear \\
\hline Flower bud presence & $\begin{array}{c}\text { Not } \\
\text { applicable }\end{array}$ & $\begin{array}{c}\text { Not } \\
\text { applicable }\end{array}$ & Yes & Not clear & Not clear \\
\hline
\end{tabular}

Note. $\mathrm{CBT}=$ Cupule-bract transition stage 
Rafflesia azlanii and Rafflesia cantleyi buds with Tetrastigma rafflesiae. The transverse section of $T$. rafflesiae infected by $R$. azlanii for cupule stage are shown in Figures 5(a) and (b), the R. cantleyi buds with the cupule-bract transition (CBT) stage is shown in Figure 5(c) and bract stage in Figure 5(d). Rafflesia azlanii buds show the periderm cells marked as 'PER' located at the root's outer surface with a bit of pith located in the centre of the root stem near the vascular bundle. The parasite-affected tissues marked as 'PAT' penetrate the xylem tissues in Figures 5(a) and 5(b). Parasite cells normally have a larger nucleus with usually two nucleoli (Rutherford, 1970). According to Pérez-de-Luque (2013), epidermal cells at the haustorium apex were enlarged to form the intrusive cells where the cortex cells divided for the penetration process. Nikolov et al. (2014b) reported that typical angiosperm holoparasites developed a haustorium that absorbed host nutrients and water. However, in Rafflesiaceae, the endophyte was not called haustorium since it does not connect an external shoot to the host. Thus, the parasite-affected tissue (PAT) resembles the host tissue stretched by the parasite growth.

The flower bud shape marked as 'FB' in Figures 5(a) and 5(b) shows a teardropshaped body only on the cupule stage. It agrees with Nikolov et al. (2014b), who reported that the Rhizanthes lowii, a parasite under Rafflesiaceae, also clearly showed a teardrop-shaped protocorm with a smooth texture. In this study, the flower bud of the $R$. azlanii was located between the cortex and parasite-affected tissues. The vascular bundles of the host are arranged in an alternate manner that contains seven branches of phloems and xylems. Figure 5(b) shows vascular cambium, which contains meristematic tissue between the phloem and xylem tissues. The periderm cell is seen in the figure for the CBT stage of $R$. cantleyi with $T$. rafflesiae. The image shows a bit of pith, ' $\mathrm{P}$ ' in Figure 5(c), located in the centre of the root stem close to the vascular bundles. The parasiteaffected tissues penetrated the host xylem tissues and ruptured Figures 5(c) and 5(d). Vascular bundles are arranged in an alternate manner that contains eight to nine phloem and xylem tissues Figure 5(c). A total of 12 to 14 branches of ruptured phloems and xylems [Figure 5(d)] next to the parasiteaffected tissue can be seen in Figure 5(d). Based on the observation in Figure 5, the parasite penetrated and stayed in the host xylem. Nikolov et al. (2014b) supported this and claimed that Rafflesia endophytes live in the xylem area and later rises to the host epidermal layer.

From the observation, as the development stage progresses, the number of vascular bundles branches increases as the size increases. Parasite-affected tissue penetration was unclear in two stages of bud development (i.e., CBT stage and bract stage). According to Mursidawati et al. (2019), regarding the development of endoparasite on R. patma, they found that the parasite grows without any visible vascular tissues within the cambium as cell clusters. It can be seen within the parasite- 


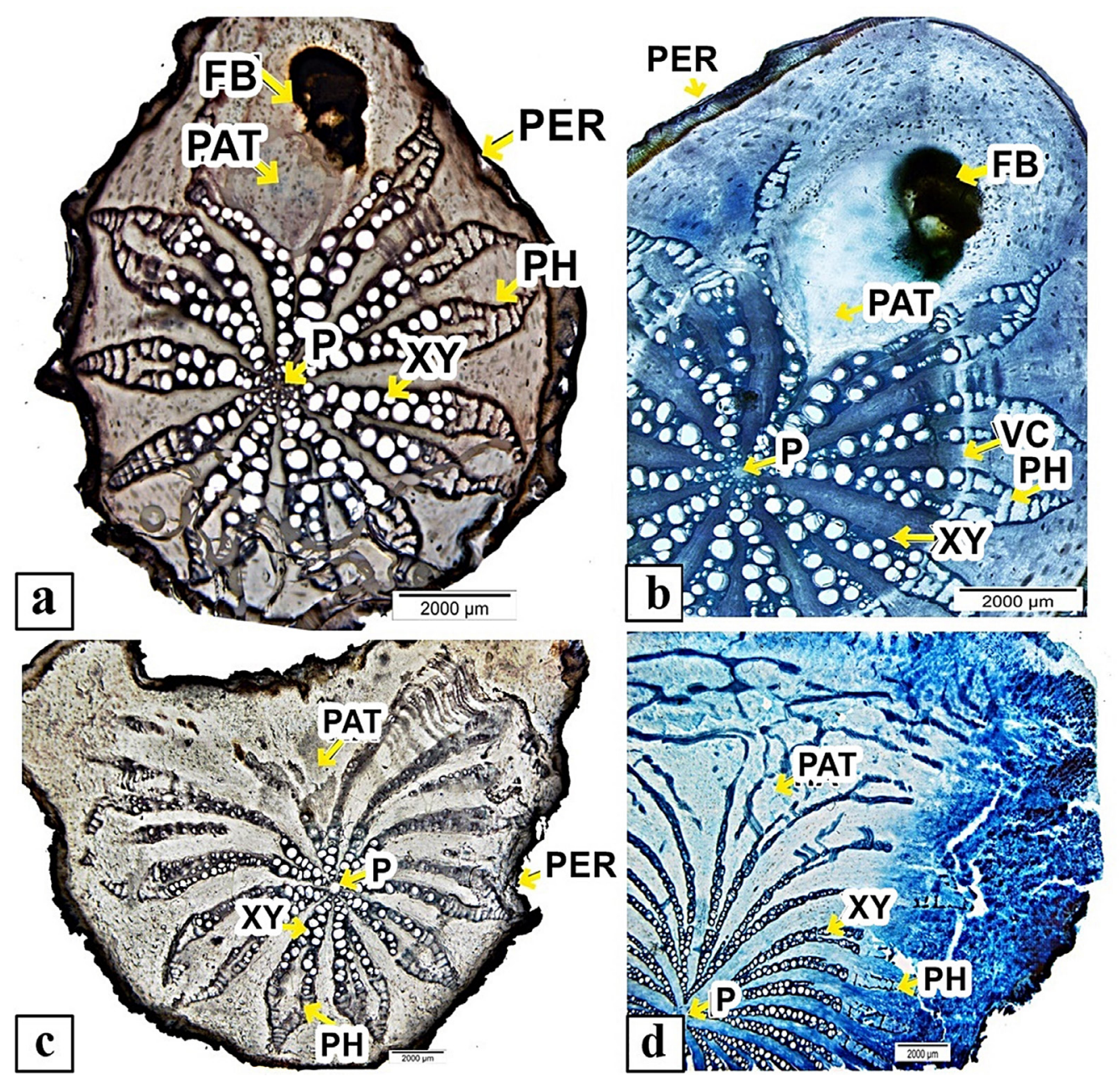

Figure 5. Transverse section of Rafflesia azlanii buds that attached with host (a) and (b), transverse section of Rafflesia cantleyi buds that attached to the host (c) and (d) (Scale: a, b, c, d = 2,000 $\mu \mathrm{m}$ )

Note. PER $=$ Periderm $; \mathrm{FB}=$ Flower bud; $\mathrm{PAT}=$ Parasite-affected tissue $; \mathrm{VC}=$ Vascular cambium; $\mathrm{PH}=$ Phloem; XY = Xylem; $\mathrm{P}=$ Pith

affected tissues in Figure 4. Mursidawati et al. (2020) claimed that the flower tissue comprises three types of proximal region, tissue with non-elongated cells in the middle and distal regions. However, these tissues cannot be seen using this method because of redundant tissues due to the thick size of the specimen cutting.
As for host-parasitic interaction, it was found that at the early stages of the bud for both species, the parasitic intrusion of Rafflesia invading the $T$. rafflesiae only goes across the phloem region while the xylem host remains untouched. However, in late buds for both species, the Rafflesia tissue invaded both the xylem and phloem 
of the host. A. Wicaksono (personal communication, December 18, 2020) mentioned that for Rhizanthes infanticida, which is also under the Rafflesiacea family, the parasite penetrated deeply into the host's xylem until reaching its core. Unlike $R$. azlanii and $R$. cantleyi, the penetration of the parasite extended only to the proximal area of the host xylem for the last bud. The movement of PAT in Figures 5(a) and 5(b) clearly shows a pointed tissue towards the host xylem region. This type of movement differed from other endoparasites observed in Cytinus species in De Vega et al. (as cited in Mursidawati et al., 2020, p. 112). The study shows that in Cytinus species, the parasite occupies the entire region of the xylem as sinker cells, whereas in Figure 5(a) and Figure 5(b), the parasite only penetrates towards one or two vascular bundles, as seen in R. patma (Mursidawati et al., 2020), while the remaining vascular bundles continued to grow normally. As shown in Figure 5, the number of host vascular bundles infected by Rafflesia has increased by stages. One vascular bundle infected for cupule stage, two vascular bundles for CBT stage and three host vascular bundles ruptured by Rafflesia for bract stage for $R$. azlanii and $R$. cantleyi. This movement was believed to minimise the host vascular damage to allow the host to live as the Rafflesia flower is huge and takes longer time to develop in the host tissue. It could answer how the host can tolerate numerous Rafflesia buds on the vine and still survive and manage to supply nutrients to the world's biggest flower. More buds growing in multiple angles will cause more damage to the host compared to more buds growing in the same growth direction (Mursidawati et al., 2020).

\section{Anatomy under Micrographology SEM}

Tetrastigma rafflesiae. Figures 6(a) and 6(b) show the transverse sections of $T$. rafflesiae root and young stem captured from micrographology SEM. There is no penetration of any parasite-affected cells since it was a non-infected host. For the root section, only one layer of epidermis cell is located at the root's outer surface, with a bit of pith located at the pith of the root stem. A small cortex area is observed between the epidermis and vascular bundle consisting of a few layers of parenchyma tissues. Vascular bundles are arranged alternately with 10-12 branches of phloems and xylems. There was no ruptured cell by the parasite. There is also one layer of epidermis cell at the outer surface for the young stem in Figure 6(b). A large-sized pith can be seen in the centre of the root stem near the vascular bundles, with a small cortex located between the epidermis and vascular bundles. It is in accordance with the previous report stating that the vascular bundles are arranged in an enclosed manner with a single ring containing the phloem and xylem (Crang et al., 2018). According to Marcati et al. (2014), the root xylem of Citharexylum myrianthum has wider vessels than the stem xylem. It can be seen in Figure 5 where the root xylem vessels were wider and larger than the stem xylem. The root wood is more vulnerable to embolism than a stem wood, and this could be better to have wider vessels under water stress (Marcati et al., 2014). 


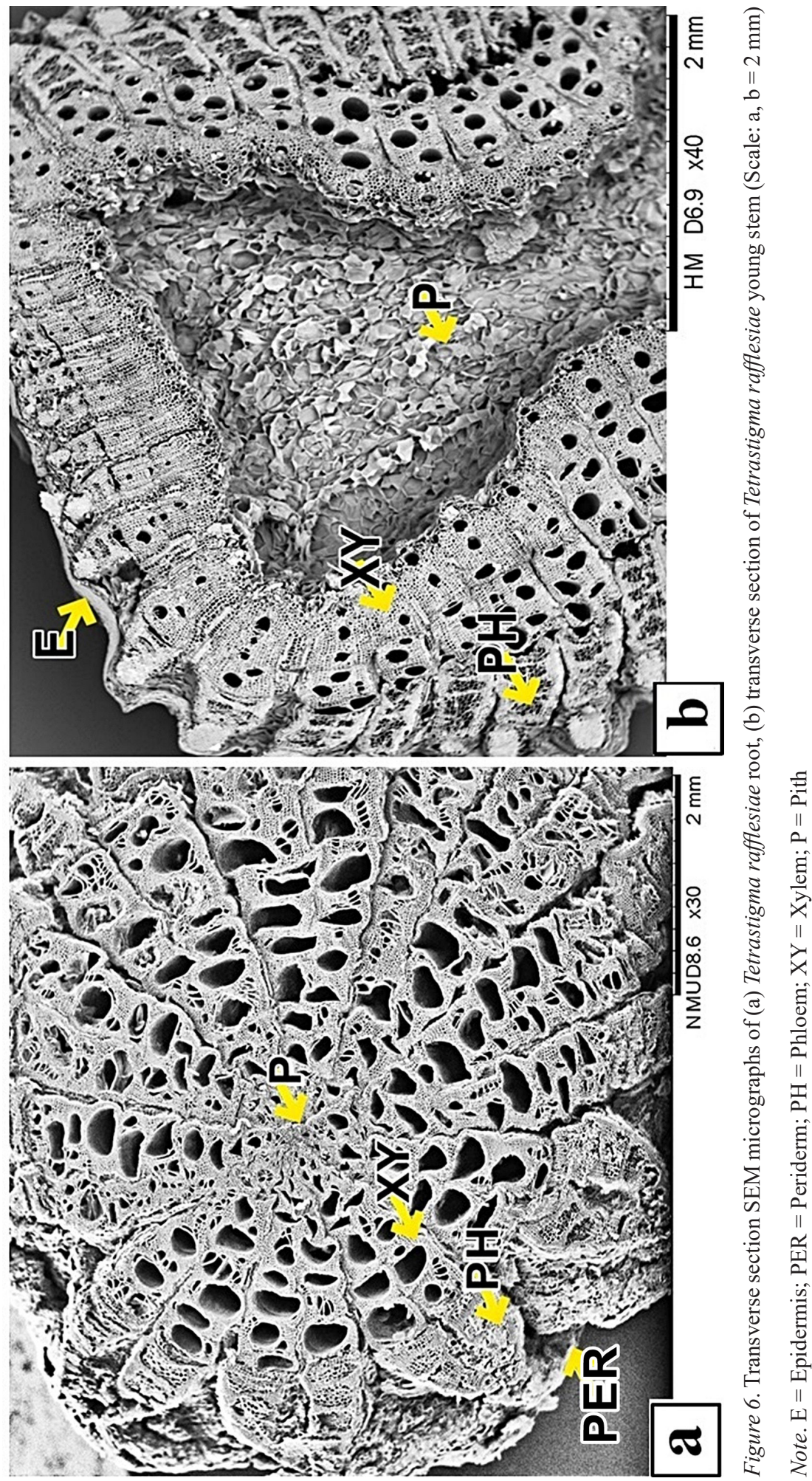


Rafflesia azlanii and Rafflesia cantleyi buds with Tetrastigma rafflesiae. Figure 7(a) and Figure 7(b) show that T. rafflesiae are infected by $R$. cantleyi in the cupule stage (a) and the bract stage (b). In contrast, Figure 7 (c) shows that $T$. rafflesiae is infected by $R$. azlanii during the cupule stage. The $R$. azlanii bud attached to $T$. rafflesiae shows the periderm cell located at the root outer surface with a bit of pith located in the centre of the root stem. From the figure, the penetration of parasitic Rafflesia inside the infected host tissues into the xylem can be seen clearly. Vascular bundles are arranged alternately and contain eight to twelve branches of phloems and xylems, as shown in Figure 7(c). For the same stage for $R$. cantleyi, the periderm cell is located at the outer surface of the root, with a bit of pith located in the centre of the root stem. Parasite-affected tissue penetrating the host xylem tissues and rupturing the tissues. Vascular bundles of T. rafflesiae are arranged in an alternate manner containing seven to eight branches of phloems and xylems and are ruptured by parasitic Rafflesia tissue. For the brown bracts stage, the $R$. cantleyi bud shows the PAT located across the vascular bundles of infected $T$. rafflesiae in Figure 7(b). A study on R. patma conducted by Mursidawati et al. (2020a) found that the vascular bundle was found in the middlelate of the perigone lobe where oddly shown only xylem vascular element in the middle. It was concluded that the absence of phloem might signify the nature of holoparasite as it does not produce its foods. However, in this study, only Rafflesia buds were selected without the flowers. Therefore, no xylem was found. The R. patma involved flower only, with xylem, no phloem and one type of vascular parenchyma. Furthermore, it was believed that the vascular parenchyma might be involved in the distribution of water and nutrients (Mursidawati et al., 2020). It agrees with de Vega et al.'s study (as cited in Mursidawati et al., 2020, p. 112), using Cytinus (Cytinaceae), a holoparasitic plant parenchyma tissue that mediates water transport between host-parasite xylem.

Figure 7(b) shows a shoot apex of $R$. cantleyi that formed. Nikolov et al. (2014b) mentioned that the shoot meristem in Rafflesiaceae grows through dense and hard host vine tissue before it emerges. It is to protect the developing flora meristem as it erupts through the host. The pith is narrow and located in the centre of the root stem near the vascular bundles. Parasite-affected tissues penetrated the xylem tissues and ruptured the tissues. As a result, vascular bundles of $T$. rafflesiae are arranged in an alternate manner that contains eight to twelve branches of phloems and xylems. According to Cocoletzi et al. (2016), a holoparasite is a parasite that establishes both the xylem and phloem connections from the host. It can be seen clearly in Figures 7(a) and 7(c), where the parasiteaffected tissues penetrate both host xylems and phloems.

The micrographs of the SEM image cannot be used for measurement due to the shrinkage process during the drying process that changed the size of the samples. The longest length for each characteristic was 

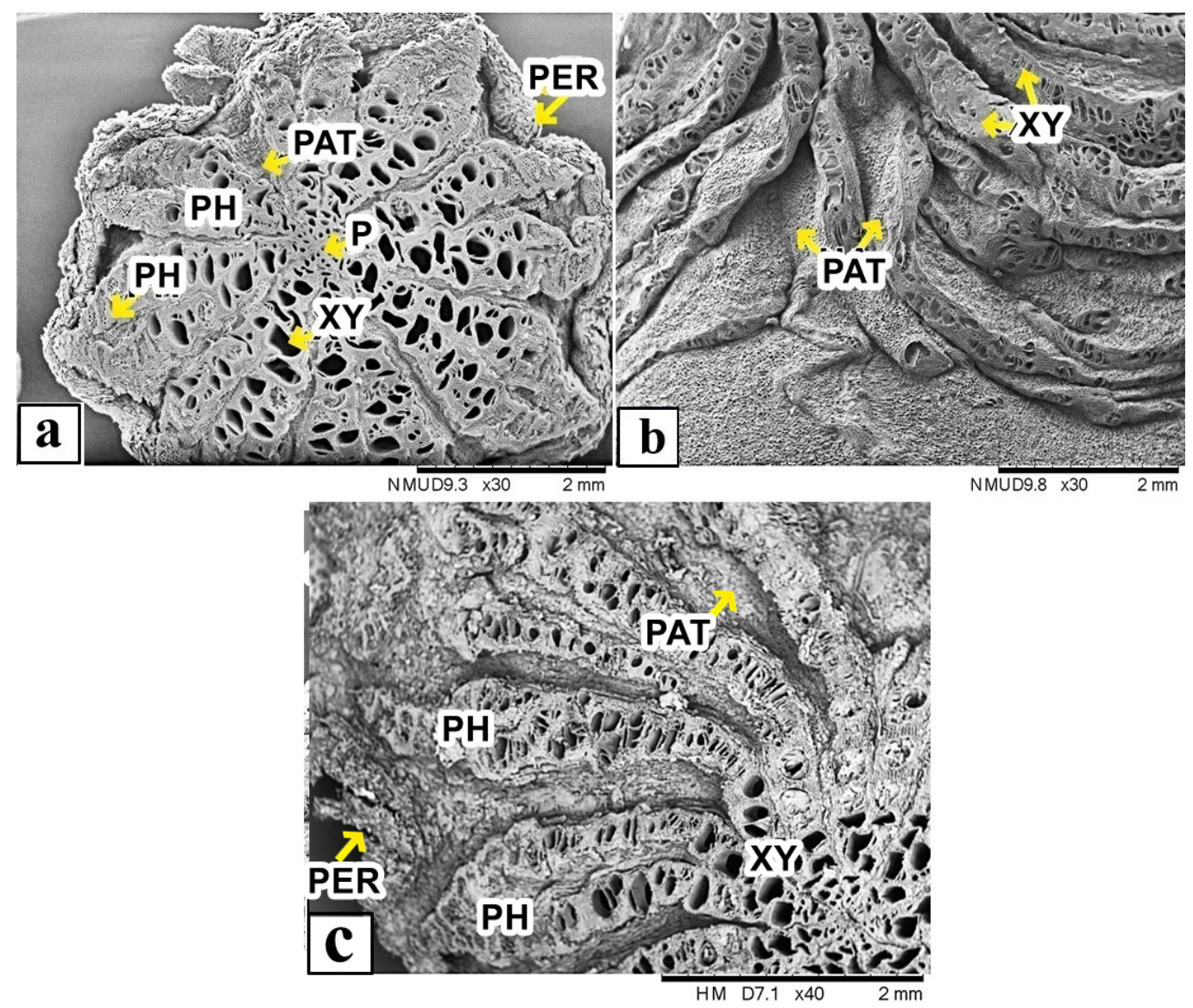

Figure 7. SEM micrographs of transverse section of (a-b) Rafflesia cantleyi attached to the host and (c) cross section of Rafflesia azlanii bud attached with the host (Scale: a, b, c $=2 \mathrm{~mm}$ )

Note PER $=$ Host periderm PH $=$ Host phloem XY = Host xylem; PAT $=$ Parasite-affected tissue of the host; $\mathrm{P}=$ Host pith

when the buds reached the bract stage as the size was bigger than other stages. Only a young stem of $T$. rafflesiae has a different vascular bundle shape, enclosed with a single ring. Only the parenchyma cells layer can be seen clearly for the young stem due to the softness of the wood and caused a less thick layer on the slide. The length of the vascular bundle and the parasite-affected tissues cannot be seen clearly for the CBT and bracts stages. It is due to the penetration process by the parasite tissue in the host (woody part) and caused the slow growth of the buds. The microscopic analyses of host-parasitic relationships between both Rafflesia species and the hosts revealed the presence of pointed intrusions in the point of attachment. The pointed intrusions which penetrated inside between 1-3 of vascular bundles of $T$. rafflesiae were believed to minimise the damage. In this study, the penetration of Rafflesia inside the host has 
shown a similar trend where the number of host vascular bundles infected increased by stages for both species in which one vascular bundle infected for cupule stage, two vascular bundles for CBT stage and three host vascular bundles ruptured by Rafflesia for bract stage. It can be speculated that fewer ruptured host vascular bundles may lead to the longevity of Rafflesia growth in the host.

\section{CONCLUSION}

This anatomical study used a sliding technique to demonstrate the early stage of Rafflesia buds (i.e., cupule stage). The anatomical characteristics in the later stages cannot be observed clearly. The parasitic intrusion of Rafflesia invading the host only goes across the phloem region for the early stage. In contrast, in the late bud for both species, the Rafflesia tissue invaded both the host's xylem (proximal region) and phloem. The movement of parasite intrusion of Rafflesia for both species has shown a pointed tissue towards the host as this was believed to minimise the damage of the host plant. A light microscope with a digital camera is sufficient to observe the penetration of the parasite-affected tissues inside the vascular bundle. In contrast, the SEM is more suitable for observing details. The sliding technique used has damaged the samples of soft bud tissues. Thus, an alternative method should be applied to get a better view of the anatomical structures of both species. Further work using different methods such as the rotating technique using the paraffin wax method may improve the study as shown in other Rafflesia studies. In addition, similar future studies may be conducted to study the structure of vascular bundles between species with greater detail. Furthermore, the wood anatomy of the host can be studied in detail in terms of differences and similarities among different species. It will enhance our understanding of the interaction between Rafflesia species with their host.

\section{ACKNOWLEDGEMENTS}

The authors are grateful to Yayasan EMKAY and Universiti Teknologi MARA (UiTM) for providing research funding for this study (600-RMC/LESTARI SDG-T 5/3). Thanks to the Forestry Department Peninsular Malaysia and Perak Forestry Department staff for facilitating the issuance of sample collection and transport permits. We extend our thanks to Prof. Emeritus Dato' Dr Abdul Latiff Mohamad and Mr Adhityo Wicaksono (Genbinesia Foundation, Indonesia) for their valuable inputs.

\section{REFERENCES}

Aiman Hanis, J., Abu Hassan, Nurita, A. T., \& Che Salmah, M. R. (2014). Community structure of termites in a hill dipterocarp forest of Belum-Temengor Forest Complex, Malaysia: Emergence of pest species. The Raffles Bulletin of Zoology, 62, 3-11.

Bell, T. L., Adams, M. A., \& Rennenberg, H. (2011). Attack on all fronts: Functional relationships between aerial and root parasitic plants and their woody hosts and consequences for ecosystems. Tree Physiology, 31(1), 3-15. https://doi. org/10.1093/treephys/tpq108 
Cameron, D. D., \& Seel, W. E. (2007). Functional anatomy of haustoria formed by Rhinanthus minor: Linking evidence from histology and isotope tracing. New Phytologist, 174(2), 412-419. https://doi.org/10.1111/j.14698137.2007.02013.x

Cocoletzi, E., Angeles, G., Ceccantini, G., Patrón, A., \& Ornelas, J. F. (2016). Bidirectional anatomical effects in a mistletoe-host relationship: Psittacanthus schiedeanus mistletoe and its hosts Liquidambar styraciflua and Quercus germana. American Journal of Botany, 103(6), 986-997. https://doi.org/10.3732/ajb.1600166

Crang, R., Lyons-Sobaski, S., \& Wise, R. (2018). Plant anatomy: A concept-based approach to the structure of seed plants. Springer.

Hibberd, J. M., \& Jeschke, W. D. (2001). Solute flux into parasitic plants. Journal of Experimental Botany, 52(363), 2043-2049. https://doi. org/10.1093/jexbot/52.363.2043

Lopes, W. A., Souza, L. A., Moscheta, I. M., Albiero, A. L., \& Mourão, K. S. (2008). A comparative anatomical study of the stems of climbing plants from the forest remnants of Maringa, Brazil. Gayana Botanica, 65(1), 28-38. http://doi. org/10.4067/S0717-66432008000100005

Malaysian Nature Society. (2013). About Belum Temengor and MNS. https:// mnshornbillvolunteerprogramme.wordpress. com/about/

Marcati, C. R., Longo, L. R., Wiedenhoeft, A., \& Barros, C. F. (2014). Comparative wood anatomy of root and stem of Citharexylum myrianthum (Verbenaceae). Rodriguesia, 65(3), 567-576. https://doi.org/10.1590/2175-7860201465301

Mursidawati, S., \& Irawati (2017). Biologi konservasi Rafflesia [Conservation Biology Rafflesia]. LIPI Press.

Mursidawati, S., \& Sunaryo (2012). Studi anatomi endofitik Rafflesia patma di dalam inang Tetrastigma sp. [Study of the endophytic anatomy of Rafflesia patma in the host Tetrastigma sp.]. Buletin Kebun Raya, 15(2), 71-80.

Mursidawati, S., \& Wicaksono, A. (2020). Tissue differentiation of the early and the late flower buds of Rafflesia patma Blume. Journal of Plant Development, 27, 19-32. https://doi. org/10.33628/jpd.2020.27.1.19

Mursidawati, S., Wicaksono, A., \& Teixeira da Silva, J. A. (2019). Development of the endophytic parasite, Rafflesia patma Blume, among host plant (Tetrastigma leucostaphylum (Dennst.) Alston) vascular cambium tissue. South African Journal of Botany, 123, 382-386. https://doi. org/10.1016/j.sajb.2019.03.028

Mursidawati, S., Wicaksono, A., \& Teixeira da Silva, J. A. (2020). Rafflesia patma Blume flower organs: histology of the epidermis and vascular structures, and a search for stomata. Planta, 251, 112. https://doi.org/10.1007/s00425-020-034025

Nikolov, L. A., Staedler, Y. M., Manickam, S., Schönenberger, J., Endress, P. K., Kramer, E. M., \& Davis, C. C. (2014a). Floral structure and development in Rafflesiaceae with emphasis on their exceptional gynoecia. American Journal of Botany, 101(2), 225-243. https://doi.org/10.3732/ ajb. 1400009

Nikolov, L. A., Tomlinson, P. B., Manickam, S., Endress, P. K., Kramer, E. M., \& Davis, C. C. (2014b). Holoparasitic Rafflesiaceae possess the most reduced endophytes and yet give rise to the world's largest flowers. Annals of Botany, 114(2), 233-242. https://doi.org/10.1093/aob/mcu114

Pace, M. R., Angyalossy, V., \& Acevedo-rodr, P. (2018). Structure and ontogeny of successive cambia in Tetrastigma (Vitaceae), the host plants of Rafflesiaceae. Journal of Systematics and Evolution, 56(4), 394-400. https://doi. org $/ 10.1111 /$ jse. 12303

Pérez-de-Luque, A. (2013). Haustorium invasion into host tissues. In Parasitic Orobanchaceae (pp. 
75-86). Springer. https://doi.org/10.1007/9783-642-38146-1

Razak, K. A., Che Hasan, R., Kamarudin, K. H., Haron, H. N., Sarip, S., Dziyauddin, R. A., \& Fathi, S. (2015). Transroyal: Multi-inter-transdisciplinary geo-biosphere research initiatives in the Royal Belum and Temengor Forest Complex (RBTFC) Gerik Perak. http://mjiit.utm.my/ icsi2015/

Rutherford, R. J. (1970). The anatomy and cytology of Pilostyles thurberi Gray (Rafflesiaceae). Aliso: A Journal of Systematic and Evolutionary Botany, 7(2), 263-288. https://doi.org/10.5642/ aliso. 19700702.13

Susatya, A. (2020). The growth of flower bud, life history, and population structure of Rafflesia arnoldii (Rafflesiaceae) in Bengkulu, Sumatra, Indonesia. Biodiversitas Journal of Biological Diversity, 21(2), 792-798. https://doi. org/10.13057/biodiv/d210247

Syamsurina, A. (2018). Taburan, fiziko-kimia tanah, anatomi dan mikroskopik Tetrastigma rafflesiae Planch. di Perak, Pahang, dan Kelantan [Distribution, soil physico-chemistry, anatomy and microscopy of Tetrastigma rafflesiae Planch. in Perak, Pahang, and Kelantan] [Unpublished Doctoral dissertation]. Universiti Kebangsaan Malaysia.
Těšitel, J. (2016). Functional biology of parasitic plants: A review. Plant Ecology and Evolution, 149(1), 5-20. https://doi.org/10.5091/ plecevo.2016.1097

Tolivia, D., \& Tolivia, J. (1987). Fasga: A new polychromatic method for simultaneous and differential staining of plant tissues. Journal of Microscopy, 148(1), 113-117. https://doi. $\operatorname{org} / 10.1111 / \mathrm{j} .1365-2818.1987 . t b 02859 . x$

Twyford, A. D. (2017). New insights into the population biology of endoparasitic Rafflesiaceae. American Journal of Botany, 104(10), 1433-1436. https:// doi.org/10.3732/ajb.1700317

Twyford, A. D. (2018). Parasitic plants. Current Biology, 28(16), R857-R859. https://doi. org/10.1016/j.cub.2018.06.030

Wicaksono, A. (2015). Short Communication: Attempted callus induction of holoparasite Rafflesia patma Blume using primordial flower bud tissue. Nusantara Bioscience, 7(2), 96-101. https://doi.org/10.13057/nusbiosci/n070206 
